\title{
Riwayat KEK dan anemia pada ibu hamil tidak berhubungan dengan kejadian stunting pada anak usia 6-23 bulan di Kecamatan Sedayu, Bantul, Yogyakarta
}

\author{
CED and maternal anemia did not associate with stunting in children 6-23 months in Sedayu \\ Subdistrict, Bantul, Yogyakarta
}

Kristiana Tri Warsini ${ }^{1}$, Hamam Hadi², Detty Siti Nurdiati ${ }^{3}$

\begin{abstract}
Background: Quality of human resource was built since human being was in the womb. Pregnant mother's health had significant impact on fetus. Pregnant mother's with anemia and CED would surely have significant impact on the fetus in their womb because it would make low birth weight. If a child with low birth weight can not catch up grow, it was highly possible that they would suffer from stunting.

Objectives: The aim of this study was to identify the relationship between nutritional status of pregnant mother with stunting in children 6-23 age month in Sedayu, Bantul, Yogyakarta.

Methods: It was observational study with case-control design. The number of samples were 252 children aged 6-23 months. All of stunting children aged 6-23 months in Sedayu subdistrict were selected as samples. Cases and controls samples were matching based on age. Data were collected using structured questionnaire to find out the identity of the children aged 6-23 month, identity of respondents, the nutritional status of the children aged 6-23 month, the history of nutritional status of the pregnant mothers' and sociodemographic. Anthropometric measurement used microtoise to find out parent's height, infantometer to find out children length, semi-quantitative food frequency questionnaire (SQ-FFQ) and food models were used as instrument. The data was analyzed using univariate analysis, bivariate analysis with chisquare test, and multivariate analysis with multiple logistic regression.

Results: The bivariate analysis showed that anemic history during pregnancy was the risk factor of stunting, but it was not statistically significant ( $p=0.13$, OR:1.5, 95\% Cl:0.85-2.73). The CED history during pregnancy was not the risk factor of the stunting incident ( $p=0.23$, OR:0.7, 95\% Cl:0.37-1.31). Other factors related to the stunting incidence were mother's height ( $p=0.01$, OR:2.04, 95\% Cl:1.14-3.65), the history of low birth weight ( $p=0.03$, OR:3.03, 95\% Cl:1.09-8.33), and food insecurity ( $p=0.04$, OR:2.7, 95\% Cl:1.04-7.00). The multivariate analysis showed that mother's height was correlated with the stunting incidence in Sedayu subdistrict.

Conclusion: Factors that influence the incidence of stunting in children aged 6-23 month were pregnant mother with anemia, history of low birth weight, food insecurity, and stunted mother. Stunted mother was associated with the incidence of stunting.
\end{abstract}

KEY WORDS: anemia, CED, growth disorder, pregnant women, risk factors

\begin{abstract}
ABSTRAK
Latar belakang: Kualitas sumber daya manusia terbentuk sejak dalam kandungan. Kesehatan ibu saat hamil akan sangat mempengaruhi kesehatan janin yang dikandungnya. Ibu hamil yang anemia dan menderita kekurangan energi kronis (KEK) tentu akan mempengaruhi kesehatan janin yang dikandungnya, karena akan menyebabkan bayi lahir dengan berat yang rendah. Bila tidak bisa tumbuh kejar, bayi BBLR kemungkinan besar akan menderita stunting.
\end{abstract}

\footnotetext{
${ }^{1}$ Dinas Kesehatan Kabupaten Wonogiri, Jl. Jend. A. Yani No 44 Wonogiri, email: kristiana.tw@gmail.com

2 Program Studi S1 IImu Gizi Universitas Alma Ata, Jl. Ring Roas Barat Daya No 1, Taman Tirto, Kasihan, Bantul, Yogyakarta, email: hamamhadi99@gmail.com

${ }^{3}$ Bagian Obstetri dan Ginekologi RSUP Dr. Sardjito, Jl.Kesehatan,Yogyakarta, email: dnurdiaty@yahoo.com
} 
Tujuan: Untuk mengetahui hubungan antara status gizi ibu saat hamil dengan kejadian stunting pada anak usia 6-23 bulan di Kecamatan Sedayu, Kabupaten Bantul.

Metode: Penelitian ini merupakan penelitian observasional dengan desain case-control. Jumlah sampel penelitian sebanyak 252 anak berusia 6-23 bulan yang berasal dari 4 desa di Kecamatan Sedayu. Semua anak stunting usia 6-23 bulan diambil sebagai sampel, dengan matching umur kasus dan kontrol. Pengambilan data menggunakan kuesioner terstruktur untuk mengetahui identitas anak usia 6-23 bulan, identitas responden, status gizi anak usia 6-23 bulan, riwayat status gizi ibu saat hamil, dan data sosiodemografi. Pengukuran antropometri terhadap tinggi badan orang tua dengan microtoise dan panjang badan anak dengan infantometer serta untuk SQ-FFQ menggunakan food model. Data dianalisis dengan menggunakan analisis univariat (deskriptif), bivariat (chi-square), dan multivariat (regresi logistik).

Hasil: Hasil bivariat menunjukkan riwayat anemia saat hamil merupakan faktor risiko terjadinya stunting tetapi secara statistik tidak signifikan ( $p=0,13$, OR=1,5,95\% $\mathrm{Cl}=0,85-2,73)$. Riwayat $K E K$ saat hamil bukan faktor risiko terhadap kejadian stunting ( $p=0,23, O R=0,7,95 \% C l=0,37-1,31)$. Faktor lain yang berhubungan dengan kejadian stunting adalah tinggi badan ibu $(p=0,01, O R=2,04,95 \% C l=1,14-3,65)$, riwayat $B B L R$ $(p=0,03, O R=3,03,95 \% C l=1,09-8,33)$, dan rawan pangan $(p=0,04, O R=2,7,95 \% C l=1,04-7,00)$. Hasil analisis multivariat adalah tinggi badan ibu berhubungan dengan kejadian stunting di Kecamatan Sedayu, Bantul, Yogyakarta.

Kesimpulan : Faktor yang mempengaruhi kejadian stunting adalah ibu hamil yang menderita anemia, mempunyai riwayat BBLR, rumah tangga rawan pangan dan tinggi badan ibu yang kurang. Pada analisis multivariat yang berhubungan dengan kejadian stunting adalah tinggi badan ibu yang kurang.

KATA KUNCI: anemia, KEK, stunting, ibu hamil, faktor risiko

\section{PENDAHULUAN}

Dalam era globalisasi diperlukan sumber daya manusia yang berkualitas. Untuk mendapatkan manusia yang berkualitas, perlu dimulai sejak di dalam kandungan. Kecukupan asupan zat gizi ibu hamil penting agar bayi yang dikandungnya sehat dan lahir dengan berat badan yang normal. Anak perlu dipersiapkan dengan baik agar bisa tumbuh dan berkembang dengan optimal. Untuk dapat tumbuh dan berkembang optimal, diperlukan interaksi lingkungan yang baik (1).

Salah satu akibat kurang gizi yang berdampak buruk terhadap kualitas hidup anak dalam mencapai tumbuh kembang yang optimal sesuai potensi genetiknya adalah stunting. Stunting merupakan suatu indikator kependekan dengan menggunakan rumus tinggi badan menurut umur (TB/U). Indikator TB/U menggambarkan status gizi yang bersifat kronis yang terjadi sebagai akibat dari akumulasi beberapa situasi yang berlangsung lama seperti kemiskinan, pola asuh yang belum tepat, dan kebersihan/higiene sanitasi yang kurang baik, sehingga mengakibatkan menderita penyakit yang berulang (2). Balita pendek adalah balita dengan status gizi kurang yang diukur dari panjang badan atau tinggi badan menurut umurnya. Standar baku World Health Organization (WHO) 2005 untuk balita dengan status gizi kurang bila nilai skor z-nya di bawah -2 SD (3). Dampak dari balita yang menderita stunting di antaranya adalah memiliki risiko lebih besar untuk menderita penyakit dan mengalami kematian, memiliki prestasi yang jelek di sekolah, pada masa dewasanya akan mengalami penurunan produktivitas kerja, dan akan mengakibatkan penurunan pendapatan lebih kurang 10\% (4-6). Hasil riset kesehatan dasar (Riskesdas) tahun 2013, prevalensi kependekan Provinsi Daerah Istimewa Yogyakarta (DIY) paling rendah di Indonesia yaitu 27,3\% (7). Prevalensi kependekan di Provinsi DIY tahun 2013 mengalami peningkatan sebesar 4,8\% jika dibandingkan dengan hasil Riskesdas tahun $2010(22,5 \%)(2)$.

Berdasarkan Data Profil Kesehatan Kabupaten Bantul 2012 dan hasil pemantauan status gizi (PSG) Kabupaten Bantul tahun 2012, masih ditemukan kasus balita stunting dengan prevalensi $18,08 \%$, prevalensi ibu hamil kurang energi kronis (KEK) adalah $13,86 \%$, cakupan air susu ibu (ASI) eksklusif 
masih $63,51 \%$, cakupan K4 baru mencapai $89,7 \%$, masih adanya kasus anemia ibu hamil sebesar $28,67 \%$ dan masih adanya kasus berat bayi lahir rendah (BBLR) yaitu sebesar 3,97\% (8).

Kecamatan Sedayu merupakan salah satu kecamatan di Kabupaten Bantul dan masih ditemukan kasus stunting sebesar $16,93 \%$, prevalensi ibu hamil KEK sebesar $11,38 \%$, prevalensi anemia ibu hamil sebesar $35,18 \%$, cakupan K4 ibu hamil baru mencapai $79,64 \%$, prevalensi ASI eksklusif baru mencapai $54,29 \%$, dan masih ada kasus BBLR sebesar $6,45 \%$ (8). Tujuan dari penelitian ini adalah untuk mengetahui hubungan antara status gizi ibu saat hamil dengan kejadian stunting pada anak usia 6-23 bulan di Kecamatan Sedayu, Bantul, Yogyakarta.

\section{BAHAN DAN METODE}

Jenis penelitian ini adalah observasional dengan desain penelitian kasus kontrol. Penelitian dilakukan di Kecamatan Sedayu, Kabupaten Bantul dari bulan April hingga Juni 2014. Penelitian ini merupakan bagian dari penelitian yang berjudul "Status Gizi Ibu Hamil Baduta di Kecamatan Sedayu Kabupaten Bantul D.I Yogyakarta" yang dilaksanakan oleh Alma Ata Center for Healthy Life and Food (ACHEAF). Besar sampel dihitung dengan menggunakan rumus untuk uji hipotesis perbedaan 2 proporsi (9). Setelah dihitung, diperoleh jumlah sampel untuk masing-masing kasus dan kontrol adalah 123, karena jumlah balita stunting di Kecamatan Sedayu yang memenuhi kriteria inklusi dan eksklusi adalah 126 anak, maka semua balita tersebut diambil sebagai sampel. Perbandingan kasus : kontrol $=1: 1$ maka total sampel kasus dan kontrol adalah 252 anak. Matching umur dilakukan pada kasus dan kontrol. Kriteria inklusi kasus adalah anak stunting usia 6-23 bulan; bertempat tinggal tetap di Kecamatan Sedayu; bila keluarga mempunyai anak kembar yang stunting maka semua diambil sebagai sampel, bila dalam satu keluarga mempunyai lebih dari 1 anak yang stunting usia 6-23 bulan maka diambil anak yang tertua sebagai sampel, ibu bersedia menjadi responden dan menandatangani informed consent, anak dalam keadaan sehat, ibu mempunyai catatan riwayat kesehatan ibu dan balita (Buku KIA) kohort). Kriteria eksklusi adalah anak menderita cacat fisik pada kaki (tidak punya kaki dan kaki tidak bisa diluruskan), salah satu atau kedua orang tua dari anak meninggal, dan status anak sebagai anak angkat.

Variabel terikat adalah anak stunting usia 6-23 bulan, variabel bebas adalah status gizi ibu saat hamil (ibu hamil anemia dan ibu hamil KEK). Variabel luarnya adalah frekuensi pemeriksaan kehamilan, umur kehamilan, riwayat BBLR, jenis kelamin, riwayat penyakit infeksi, pendidikan orang tua, pekerjaan orang tua, pendapatan keluarga, ketahanan pangan rumah tangga, tinggi badan orang tua, usia pengenalan makanan pendamping ASI (MP-ASI), serta asupan energi dan protein, sementara variabel antara yaitu riwayat BBLR.

Instrumen yang digunakan adalah kuesioner yang terstruktur untuk mengetahui identitas balita, identitas orang tua, riwayat status gizi anak, riwayat status gizi ibu, riwayat kelahiran, infantometer untuk mengukur panjang badan anak dengan ketelitian $0,1 \mathrm{~cm}$, microtoise untuk mengukur tinggi badan orang tua dengan ketelitian $0,1 \mathrm{~cm}$ dan food model. Uji validitas dan reliabilitas kuesioner terhadap 30 orang ibu baduta. Kuesioner yang diujicobakan adalah kuesioner penilaian ketahanan pangan dan pengetahuan ibu. Uji validitas dan reliabilitas kuesioner menggunakan Pearson Correlation Product Moment untuk melihat korelasi dari setiap item pertanyaan terhadap total skor. Jumlah sampel (n) uji coba kuesioner adalah 30, maka derajat bebasnya adalah $n-2=30-2=28$. Hasil nilai $r$ tabel pada df 28 dan $p=0,05$ adalah 0,361 . Item pertanyaan dinyatakan valid bila nilai corrected item-total corelation $>0,361$ dan dinyatakan reliabel bila nilai alpha cronbach's $>0,361$ (10). Penelitian ini sudah memperoleh surat kelaikan etik (ethical clearance) dari Komisi Etik Penelitian Kedokteran dan Kesehatan Fakultas Kedokteran Universitas Gadjah Mada Yogyakarta dengan nomor Ref: KE/F/382/EC.

\section{HASIL}

\section{Karakteristik subjek penelitian}

Berdasarkan Tabel 1 dapat diketahui bahwa persentase anak stunting yang ibunya mempunyai 
tinggi badan kurang yaitu $62,03 \%$, sedangkan anak yang tidak stunting sebagian besar tinggi badan ibunya normal yaitu $55,49 \%$. Persentase anak stunting yang rumah tangganya rawan pangan lebih tinggi daripada anak stunting yang rumah tangganya tahan pangan yaitu $71,43 \%$.

Berdasarkan Tabel 2 dapat diketahui bahwa persentase anak stunting yang ibunya menderita anemia saat hamil lebih tinggi daripada persentase anak stunting yang ibunya saat hamil tidak menderita anemia yaitu $57,33 \%$. Persentase anak stunting yang ibunya menderita KEK saat hamil lebih rendah daripada anak stunting yang ibunya saat hamil tidak menderita KEK yaitu 43,10\%.

Hasil analisis bivariat seperti terlihat pada Tabel 3 diketahui bahwa anak stunting yang ibunya anemia saat hamil lebih tinggi daripada anak stunting yang ibunya tidak anemia saat hamil yaitu $57,33 \%$. Berdasarkan hasil uji statistik diperoleh

Tabel 1. Distribusi frekuensi karakteristik kondisi sosial ekonomi

\begin{tabular}{|c|c|c|c|c|c|}
\hline \multirow{2}{*}{$\begin{array}{c}\text { Karakteristik } \\
\text { responden }\end{array}$} & \multicolumn{2}{|c|}{$\begin{array}{l}\text { Kasus } \\
(n=126)\end{array}$} & \multicolumn{2}{|c|}{$\begin{array}{l}\text { Kontrol } \\
(n=126)\end{array}$} & \multirow[t]{2}{*}{$\mathbf{p}$} \\
\hline & n & $\%$ & $\mathbf{n}$ & $\%$ & \\
\hline \multicolumn{6}{|l|}{ Pendidikan ibu } \\
\hline Rendah & 42 & 47,73 & 46 & 52,27 & \multirow{2}{*}{0,59} \\
\hline Tinggi & 84 & 51,22 & 80 & 48,78 & \\
\hline \multicolumn{6}{|l|}{ Pendidikan ayah } \\
\hline Rendah & 43 & 48,42 & 46 & 51,69 & \multirow{2}{*}{0,69} \\
\hline Tinggi & 83 & 50,92 & 80 & 49,08 & \\
\hline \multicolumn{6}{|c|}{ Pekerjaan ibu } \\
\hline Pekerjaan tidak tetap & 106 & 51,21 & 101 & 48,79 & \multirow{2}{*}{0,41} \\
\hline Pekerjaan tetap & 20 & 44,44 & 25 & 55,55 & \\
\hline \multicolumn{6}{|l|}{ Pekerjaan ayah } \\
\hline Pekerjaan tidak tetap & 86 & 53,42 & 75 & 46,58 & \multirow[t]{2}{*}{0,15} \\
\hline Pekerjaan tetap & 40 & 43,96 & 51 & 56,04 & \\
\hline \multicolumn{6}{|l|}{ Tinggi badan ibu } \\
\hline Kurang & 49 & 62,03 & 30 & 37,97 & \multirow[t]{2}{*}{$0,01^{\prime}$} \\
\hline Normal & 77 & 44,51 & 96 & 55,49 & \\
\hline \multicolumn{6}{|l|}{ Tinggi badan ayah } \\
\hline Kurang & 46 & 54,76 & 38 & 45,24 & \multirow[t]{2}{*}{0,29} \\
\hline Normal & 80 & 47,62 & 88 & 52,38 & \\
\hline \multicolumn{6}{|l|}{ Pendapatan keluarga } \\
\hline Kurang & 45 & 53,57 & 39 & 46,43 & \multirow[t]{2}{*}{0,42} \\
\hline Baik & 81 & 48,21 & 87 & 51,79 & \\
\hline \multicolumn{6}{|l|}{ Ketahanan pangan } \\
\hline keluarga & 15 & 71,43 & 6 & 28,57 & \multirow[t]{2}{*}{0,04} \\
\hline $\begin{array}{l}\text { Rawan pangan } \\
\text { Tahan pangan }\end{array}$ & 111 & 48,05 & 120 & 51,95 & \\
\hline
\end{tabular}

*Signifikan $(p<0,05)$
Tabel 2. Distribusi frekuensi karakteristik kesehatan ibu saat hamil dan status gizi balita

\begin{tabular}{|c|c|c|c|c|c|}
\hline \multirow{2}{*}{$\begin{array}{l}\text { Karakteristik } \\
\text { responden }\end{array}$} & \multicolumn{2}{|c|}{$\begin{array}{l}\text { Kasus } \\
(n=126)\end{array}$} & \multicolumn{2}{|c|}{$\begin{array}{l}\text { Kontrol } \\
(n=126)\end{array}$} & \multirow[t]{2}{*}{ p } \\
\hline & $\mathbf{n}$ & $\%$ & $n$ & $\%$ & \\
\hline \multicolumn{6}{|l|}{$\begin{array}{l}\text { Status anemia saat } \\
\text { hamil }\end{array}$} \\
\hline Anemia & 43 & 57,33 & 32 & 42,67 & 0,13 \\
\hline Tidak anemia & 83 & 46,89 & 94 & 53,11 & \\
\hline \multicolumn{6}{|l|}{$\begin{array}{l}\text { Status KEK saat } \\
\text { hamil }\end{array}$} \\
\hline KEK & 25 & 43,10 & 33 & 56,89 & 0,23 \\
\hline Tidak KEK & 101 & 52,06 & 93 & 47,94 & \\
\hline \multicolumn{6}{|l|}{$\begin{array}{l}\text { Frekuensi kunjungan } \\
\text { pemeriksaan } \\
\text { kehamilan }\end{array}$} \\
\hline Kurang & 8 & 47,06 & 9 & 52,94 & 0,80 \\
\hline Baik & 118 & 50,21 & 117 & 49,79 & \\
\hline \multicolumn{6}{|l|}{ Umur kehamilan } \\
\hline Preterm & 55 & 51,89 & 51 & 48,11 & 0,61 \\
\hline Aterm \& Postterm & 71 & 48,63 & 75 & 51,37 & \\
\hline \multicolumn{6}{|l|}{ Jenis Kelamin } \\
\hline Laki-laki & 66 & 47,14 & 74 & 52,86 & 0,31 \\
\hline Perempuan & 60 & 53,57 & 52 & 46,43 & \\
\hline \multicolumn{6}{|l|}{ Penyakit infeksi } \\
\hline Ada infeksi & 78 & 51,32 & 74 & 48,68 & 0,61 \\
\hline Tidak ada infeksi & 48 & 48,00 & 52 & 52,00 & \\
\hline \multicolumn{6}{|l|}{ Riwayat BBLR } \\
\hline BBLR & 14 & 73,68 & 5 & 26,42 & $0,03^{*}$ \\
\hline Normal & 112 & 48,07 & 121 & 51,93 & \\
\hline \multicolumn{6}{|l|}{$\begin{array}{l}\text { Riwayat asupan } \\
\text { energi }\end{array}$} \\
\hline Kurang & 25 & 54,35 & 21 & 45,65 & 0,51 \\
\hline Cukup & 101 & 49,03 & 105 & 50,97 & \\
\hline \multicolumn{6}{|l|}{$\begin{array}{l}\text { Riwayat asupan } \\
\text { protein }\end{array}$} \\
\hline Kurang & 15 & 57,69 & 11 & 42,31 & 0,40 \\
\hline Cukup & 111 & 49,12 & 115 & 50,88 & \\
\hline \multicolumn{6}{|l|}{$\begin{array}{l}\text { Usia pengenalan MP- } \\
\text { ASI }\end{array}$} \\
\hline Tidak sesuai & 116 & 46,15 & 120 & 50,85 & 0,30 \\
\hline Sesuai & 10 & 62,50 & 6 & 37,50 & \\
\hline
\end{tabular}

*Signifikan $(p<0,05)$

nilai $\mathrm{OR}=1,5(95 \% \mathrm{Cl}=0,85-2,73)$ yang berarti ibu hamil yang anemia saat hamil berisiko 1,5 kali lebih tinggi anaknya akan menderita stunting, sedangkan ibu hamil yang menderita KEK saat hamil bukan merupakan faktor risiko kejadian stunting.

Berdasarkan Tabel 4 diketahui bahwa persentase anak stunting yang lahir dengan riwayat BBLR lebih tinggi daripada anak stunting yang lahir dengan berat badan normal yaitu $73,68 \%$. Hasil uji statistik menunjukkan nilai OR=3,03 (95\% Cl:1,09- 
8,33) yang berarti anak yang lahir dengan riwayat BBLR mempunyai risiko 3,03 kali lebih tinggi untuk menderita stunting.

Berdasarkan Tabel 5 diketahui bahwa persentase anak stunting yang tinggi badan ibunya kurang, lebih tinggi daripada persentase anak stunting yang tinggi badan ibunya normal yaitu $62,03 \%$. Hasil statistik menunjukkan nilai $\mathrm{OR}=2,04(95 \% \mathrm{Cl}: 1,14-3,65)$ yang berarti ibu yang mempunyai tinggi badan kurang akan mempunyai risiko 2,04 kali lebih tinggi anaknya akan menderita stunting. Persentase anak stunting yang keluarganya rawan pangan lebih tinggi daripada persentase anak stunting yang keluarganya tahan pangan yaitu $71,43 \%$ dengan nilai OR=2,7 (95\% Cl:1,04-7,00) yang berarti anak akan berisiko 2,7 kali lebih tinggi untuk menderita stunting pada keluarga yang rawan pangan.

Berdasarkan Tabel 6, dari beberapa model yang ada, model yang dipilih adalah model 6 karena model ini mempunyai variabel yang masuk

Tabel 3. Hubungan riwayat kesehatan ibu saat hamil dengan kejadian stunting

\begin{tabular}{|c|c|c|c|c|c|c|c|}
\hline \multirow[t]{2}{*}{ Variabel bebas } & \multicolumn{2}{|c|}{$\begin{array}{l}\text { Kasus } \\
(n=126)\end{array}$} & \multicolumn{2}{|c|}{$\begin{array}{l}\text { Kontrol } \\
(n=126)\end{array}$} & \multirow[t]{2}{*}{ OR } & \multirow[t]{2}{*}{$95 \% \mathrm{Cl}$} & \multirow[t]{2}{*}{$\mathbf{p}$} \\
\hline & $\mathbf{n}$ & $\%$ & $\mathbf{n}$ & $\%$ & & & \\
\hline \multicolumn{8}{|l|}{ Status anemia saat hamil } \\
\hline Anemia & 43 & 57,33 & 32 & 42,67 & 1,5 & $(0,85-2,73)$ & 0,13 \\
\hline Tidak Anemia & 83 & 46,89 & 94 & 53,11 & 1 & & \\
\hline \multicolumn{8}{|l|}{ Status KEK saat hamil } \\
\hline KEK & 25 & 43,10 & 33 & 56,89 & 0,7 & $(0,37-1,31)$ & 0,23 \\
\hline Tidak KEK & 101 & 52,06 & 93 & 47,94 & 1 & & \\
\hline \multicolumn{8}{|l|}{$\begin{array}{l}\text { Frekuensi kunjungan } \\
\text { pemeriksaan kehamilan }\end{array}$} \\
\hline Kurang & 8 & 47,06 & 9 & 52,94 & 0,9 & $(0,29-2,68)$ & 0,8 \\
\hline Baik & 118 & 50,21 & 117 & 49,79 & 1 & & \\
\hline \multicolumn{8}{|l|}{ Umur kehamilan } \\
\hline Preterm & 55 & 51,89 & 51 & 48,11 & 1,1 & $(0,67-1,94)$ & 0,7 \\
\hline Aterm dan Postterm & 71 & 48,63 & 75 & 51,37 & 1 & & \\
\hline
\end{tabular}

Tabel 4. Hubungan riwayat kesehatan anak dengan kejadian stunting

\begin{tabular}{|c|c|c|c|c|c|c|c|}
\hline \multirow[t]{2}{*}{ Variabel luar } & \multicolumn{2}{|c|}{$\begin{array}{c}\text { Kasus } \\
(n=126)\end{array}$} & \multicolumn{2}{|c|}{$\begin{array}{l}\text { Kontrol } \\
(n=126)\end{array}$} & \multirow[t]{2}{*}{ OR } & \multirow[t]{2}{*}{$(95 \% \mathrm{Cl})$} & \multirow[t]{2}{*}{$\mathbf{p}$} \\
\hline & $\mathbf{n}$ & $\%$ & $\mathrm{n}$ & $\%$ & & & \\
\hline \multicolumn{8}{|l|}{ Jenis kelamin } \\
\hline Laki-laki & 66 & 47,14 & 74 & 52,86 & 0,77 & $(0,46-1,31)$ & 0,31 \\
\hline Perempuan & 60 & 53,57 & 52 & 46,43 & 1 & & \\
\hline \multicolumn{8}{|l|}{ Riwayat penyakit infeksi } \\
\hline Ada infeksi & 80 & 51,61 & 75 & 48,39 & 1,18 & $(0,67-1,95)$ & 0,61 \\
\hline Tidak ada infeksi & 46 & 47,42 & 51 & 52,58 & 1 & & \\
\hline \multicolumn{8}{|l|}{ Riwayat BBLR } \\
\hline BBLR & 14 & 73,68 & 5 & 26,32 & $3,03^{*}$ & $(1,09-8,33)$ & $0,03^{*}$ \\
\hline Normal & 112 & 48,07 & 121 & 51,93 & 1 & & \\
\hline \multicolumn{8}{|l|}{ Riwayat asupan energi } \\
\hline Kurang & 25 & 54,35 & 21 & 45,65 & 1,24 & $(0,62-2,48)$ & 0,51 \\
\hline Cukup & 101 & 49,03 & 105 & 50,97 & 1 & & \\
\hline \multicolumn{8}{|l|}{ Riwayat asupan protein } \\
\hline Kurang & 15 & 57,69 & 11 & 42,31 & 1,41 & $(0,58-3,56)$ & 0,40 \\
\hline Cukup & 111 & 49,12 & 115 & 50,88 & 1 & & \\
\hline \multicolumn{8}{|c|}{ Usia pengenalan MP-ASI } \\
\hline Tidak sesuai & 51 & 50,50 & 50 & 49,50 & 1,07 & $(0,17--1,83)$ & 0,30 \\
\hline Sesuai & 75 & 49,67 & 76 & 50,33 & 1 & & \\
\hline
\end{tabular}

*Signifikan $(p<0,05)$ 
Tabel 5. Hubungan karakteristik responden tentang kondisi sosial ekonomi dengan kejadian stunting

\begin{tabular}{|c|c|c|c|c|c|c|c|}
\hline \multirow[t]{2}{*}{ Variabel luar } & \multicolumn{2}{|c|}{$\begin{array}{c}\text { Kasus } \\
(n=126)\end{array}$} & \multicolumn{2}{|c|}{$\begin{array}{l}\text { Kontrol } \\
(n=126)\end{array}$} & \multirow[t]{2}{*}{ OR } & \multirow[t]{2}{*}{$95 \% \mathrm{Cl}$} & \multirow[t]{2}{*}{$\mathbf{p}$} \\
\hline & $\mathbf{n}$ & $\%$ & $\mathbf{n}$ & $\%$ & & & \\
\hline \multicolumn{8}{|l|}{ Pendidikan ibu } \\
\hline Rendah & 42 & 47,73 & 46 & 52,27 & 0,87 & $(0,5-1,51)$ & 0,59 \\
\hline Tinggi & 84 & 51,22 & 80 & 48,78 & 1 & & \\
\hline \multicolumn{8}{|l|}{ Pendidikan ayah } \\
\hline Rendah & 43 & 48,32 & 46 & 51,69 & 0,9 & $(0,52-1,56)$ & 0,69 \\
\hline Tinggi & 83 & 50,92 & 80 & 49,08 & 1 & & \\
\hline \multicolumn{8}{|l|}{ Pekerjaan ibu } \\
\hline Pekerjaan tidak tetap & 106 & 51,21 & 101 & 48,79 & 1,31 & $(0,65-2,66)$ & 0,41 \\
\hline Pekerjaan tetap & 20 & 44,44 & 25 & 55,55 & 1 & & \\
\hline \multicolumn{8}{|l|}{ Pekerjaan ayah } \\
\hline Pekerjaan tidak tetap & 86 & 53,42 & 75 & 46,5856 & 1,46 & $(0,84-2,54)$ & 0,15 \\
\hline Pekerjaan tetap & 40 & 43,96 & 51 & 0,4 & 1 & & \\
\hline \multicolumn{8}{|l|}{ Tinggi badan ibu } \\
\hline Kurang & 49 & 62,03 & 30 & 37,98 & 2,04 & $(1,14-3,65)$ & $0,01^{*}$ \\
\hline Normal & 77 & 44,51 & 96 & 55,59 & 1 & & \\
\hline \multicolumn{8}{|l|}{ Tinggi badan ayah } \\
\hline Kurang & 46 & 54,76 & 38 & 45,24 & 1,33 & $(0,76-2,33)$ & 0,29 \\
\hline Normal & 80 & 47,62 & 88 & 52,38 & 1 & & \\
\hline \multicolumn{8}{|l|}{ Pendapatan keluarga } \\
\hline Kurang & 46 & 54,12 & 39 & 46,43 & 1,28 & $(0,46-1,41)$ & 0,42 \\
\hline Baik & 80 & 47,90 & 87 & 51,79 & 1 & & \\
\hline \multicolumn{8}{|l|}{ Ketahanan pangan keluarga } \\
\hline Rawan pangan & 15 & 71,43 & 6 & 28,57 & 2,70 & $(1,04-7,00)$ & $0,04^{*}$ \\
\hline Tahan pangan & 111 & 48,05 & 120 & 51,95 & 1 & & \\
\hline
\end{tabular}

*Signifikan $(p<0,05)$

ke dalam model itu sedikit tetapi sudah dapat menjelaskan faktor-faktor yang penting yang berhubungan dengan variabel terikat. Selain itu juga melihat kemaknaan dari OR dan nilai $\mathrm{R}^{2}$. Model 6 ini berkontribusi $5,5 \%$ terhadap kejadian stunting yang berarti bahwa besarnya pengaruh yang diberikan oleh riwayat anemia saat hamil, riwayat KEK saat hamil, riwayat BBLR, tinggi badan ibu, dan ketahanan pangan rumah tangga terhadap kejadian stunting sebesar $5,5 \%$, sementara ada $94,5 \%$ faktor lain yang tidak diteliti dalam penelitian ini yang dapat mempengaruhi kejadian stunting.

Berdasarkan model 6 dari analisis multivariat, diperoleh nilai Adjusted OR riwayat KEK saat hamil menurun dari 0,7 pada analisis bivariat menjadi 0,62 . Nilai OR pada variabel riwayat BBLR juga menurun dari 3,03 pada analisis bivariat menjadi 2,62 pada multivariat. Ada kemungkinan hubungan riwayat KEK saat hamil dengan kejadian stunting dipengaruhi oleh riwayat BBLR. Untuk membuktikan hal ini diperlukan analisis stratifikasi. Analisis stratifikasi diperlukan untuk melihat variabel luar dapat menjadi efek modifikasi atau tidak.

Berdasarkan Tabel 7, dapat dilihat bahwa pada strata riwayat BBLR, anak yang stunting banyak terjadi pada ibu yang tidak menderita KEK saat hamil yaitu $85,71 \%$. Pada strata berat bayi lahir normal, anak yang stunting banyak terjadi pada ibu yang tidak menderita KEK saat hamil yaitu $79,46 \%$. Analisis pada tiap strata, diperoleh nilai OR pada strata riwayat BBLR adalah 0,67 dan OR pada strata riwayat berat bayi lahir normal adalah 0,72 yang berarti bahwa jika ibu menderita KEK saat hamil dan anak waktu lahir mempunyai riwayat BBLR maupun tidak BBLR maka akan menjadi faktor proteksi terhadap kejadian stunting. Selisih antara Crude OR dan Maentel Haenzel OR adalah $2,86 \%$, selisih nilai OR ini $<20 \%$ yang berarti bahwa riwayat BBLR bukan merupakan variabel pengganggu (confounding) antara riwayat 
Tabel 6. Hasil analisis multivariat

\begin{tabular}{|c|c|c|c|c|c|c|c|}
\hline Variabel & $\begin{array}{c}\text { Model } 1 \\
\text { OR } \\
(95 \% \mathrm{Cl})\end{array}$ & $\begin{array}{c}\text { Model } 2 \\
\text { OR } \\
(95 \% \mathrm{Cl})\end{array}$ & $\begin{array}{c}\text { Model } 3 \\
\text { OR } \\
(95 \% \mathrm{Cl})\end{array}$ & $\begin{array}{c}\text { Model } 4 \\
\text { OR } \\
(95 \% \mathrm{Cl})\end{array}$ & $\begin{array}{c}\text { Model } 5 \\
\text { OR } \\
(95 \% \mathrm{Cl})\end{array}$ & $\begin{array}{c}\text { Model } 6 \\
\text { OR } \\
(95 \% \mathrm{Cl})\end{array}$ & $\begin{array}{c}\text { Model } 7 \\
\text { OR } \\
(95 \% \mathrm{Cl})\end{array}$ \\
\hline \multicolumn{8}{|l|}{ Riwayat anemia saat hamil } \\
\hline Anemia & $\begin{array}{c}1,63 \\
0,84-2,85\end{array}$ & $\begin{array}{c}1,65 \\
0,94-2,91\end{array}$ & $\begin{array}{c}1,57 \\
0,89-2,76\end{array}$ & $\begin{array}{c}1,57 \\
0,89-2,79\end{array}$ & $\begin{array}{c}1,57 \\
0,88-2,74\end{array}$ & $\begin{array}{c}1,59 \\
0,89-2,84\end{array}$ & $\begin{array}{c}1,58 \\
0,89-2,82\end{array}$ \\
\hline Tidak anemia & 1 & 1 & 1 & 1 & 1 & 1 & 1 \\
\hline \multicolumn{8}{|l|}{ Riwayat KEK saat hamil } \\
\hline KEK & $\begin{array}{c}0,64 \\
0,35-1,17\end{array}$ & $\begin{array}{c}0,57 \\
0,3-1,06\end{array}$ & $\begin{array}{c}0,68 \\
0,36-1,26\end{array}$ & $\begin{array}{c}0,59 \\
0,32-1,12\end{array}$ & $\begin{array}{c}0,69 \\
0,37-1,28\end{array}$ & $\begin{array}{c}0,61 \\
0,32-1,14\end{array}$ & $\begin{array}{c}0,62 \\
0,32-1,16\end{array}$ \\
\hline Tidak KEK & 1 & 1 & 1 & 1 & 1 & 1 & 1 \\
\hline \multicolumn{8}{|l|}{ Riwayat BBLR } \\
\hline BBLR & & & $\begin{array}{c}2,76 \\
0,95-8,0\end{array}$ & $\begin{array}{c}2,63 \\
0,89-7,76\end{array}$ & $\begin{array}{c}2,75 \\
0,94-7,98\end{array}$ & $\begin{array}{c}2,61 \\
0,89-7,7\end{array}$ & $\begin{array}{c}2,62 \\
0,88-7,75\end{array}$ \\
\hline Normal & & & 1 & 1 & 1 & 1 & 1 \\
\hline \multicolumn{8}{|l|}{ Pekerjaan ayah } \\
\hline Pekerjaan tidak tetap & & & & $\begin{array}{c}1,41 \\
0,83-2,4\end{array}$ & $\begin{array}{c}1,34 \\
0,79-2,28\end{array}$ & & $\begin{array}{c}1,33 \\
0,78-2,28\end{array}$ \\
\hline Pekerjaan tetap & & & & 1 & 1 & & 1 \\
\hline \multicolumn{8}{|l|}{ Tinggi badan ibu } \\
\hline Kurang & & $\begin{array}{c}2,17 \\
1,24-3,79\end{array}$ & & $\begin{array}{c}2,12 \\
1,2-3,72\end{array}$ & & $\begin{array}{c}2,09 \\
1,19-6,91\end{array}$ & $\begin{array}{c}2,09 \\
1,18-3,68\end{array}$ \\
\hline Normal & & 1 & & 1 & & 1 & 1 \\
\hline \multicolumn{8}{|l|}{ Ketahanan pangan } \\
\hline Rawan pangan & & & $\begin{array}{c}2,62 \\
0,97-7,07\end{array}$ & & $\begin{array}{c}2,45 \\
0,9-6,67\end{array}$ & $\begin{array}{c}2,53 \\
0,93-6,91\end{array}$ & $\begin{array}{c}2,38 \\
0,87-6,56\end{array}$ \\
\hline Tahan pangan & & & 1 & & 1 & 1 & 1 \\
\hline $\mathbf{R}^{2}$ & 0,01 & 0,034 & 0,036 & 0,049 & 0,039 & 0,055 & 0,0578 \\
\hline
\end{tabular}

Tabel 7. Analisis stratifikasi riwayat BBLR pada hubungan riwayat KEK dengan kejadian stunting

\begin{tabular}{|c|c|c|c|c|c|c|c|c|c|}
\hline \multirow{2}{*}{$\begin{array}{c}\text { Riwayat } \\
\text { BBLR }\end{array}$} & \multirow{2}{*}{ Riwayat KEK } & \multicolumn{2}{|c|}{ Kasus } & \multicolumn{2}{|c|}{ Kontrol } & \multirow{2}{*}{$\begin{array}{l}\text { OR strata } \\
(95 \% \mathrm{Cl})\end{array}$} & \multirow{2}{*}{$\begin{array}{c}\text { Crude } \\
\text { OR }\end{array}$} & \multirow{2}{*}{ M-H OR } & \multirow{2}{*}{$\begin{array}{c}\text { Selisih } \\
\text { OR }\end{array}$} \\
\hline & & $\mathbf{n}$ & $\%$ & $\mathbf{n}$ & $\%$ & & & & \\
\hline \multirow[t]{2}{*}{ BBLR } & KEK & 4 & 80,00 & 1 & 20,00 & $\begin{array}{c}0,67 \\
(0,03-49,05)\end{array}$ & 0,70 & 0,72 & $2,86 \%$ \\
\hline & Tidak KEK & 12 & 85,71 & 2 & 14,29 & 1 & & & \\
\hline \multirow[t]{2}{*}{ Normal } & KEK & 89 & 73,55 & 32 & 26,45 & $\begin{array}{c}0,72 \\
(0,37-1,38)\end{array}$ & & & \\
\hline & Tidak KEK & 89 & 79,46 & 23 & 20,54 & 1 & & & \\
\hline
\end{tabular}

KEK pada ibu hamil dengan kejadian stunting. Bila dilihat dari nilai OR tiap strata, ternyata OR strata riwayat BBLR tidak berbeda dengan OR strata berat bayi lahir normal atau OR 1 = OR 2, berarti bahwa riwayat BBLR bukan merupakan efek modifikasi hubungan antara riwayat KEK saat hamil dengan kejadian stunting.

Analisis stratifikasi riwayat anemia saat hamil pada hubungan riwayat BBLR dengan kejadian stunting disajikan pada Tabel 8. Pada strata riwayat anemia, persentase anak stunting yang lahir dari ibu yang menderita anemia saat hamil dan mempunyai riwayat BBLR lebih tinggi daripada persentase anak stunting yang lahir normal dan ibunya menderita anemia saat hamil yaitu 44,78\%. Pada strata anemia, diperoleh nilai $\mathrm{OR}=2,43$ yang berarti bahwa jika ibu menderita anemia saat hamil dan anak lahir dengan BBLR maka anak akan menderita 
Tabel 8. Analisis stratifikasi riwayat anemia pada hubungan riwayat BBLR dengan kejadian stunting

\begin{tabular}{|c|c|c|c|c|c|c|c|c|c|}
\hline \multirow{2}{*}{$\begin{array}{c}\text { Riwayat } \\
\text { anemia }\end{array}$} & \multirow{2}{*}{$\begin{array}{l}\text { Riwayat } \\
\text { BBLR }\end{array}$} & \multicolumn{2}{|c|}{ Kasus } & \multicolumn{2}{|c|}{ Kontrol } & \multirow{2}{*}{$\begin{array}{l}\text { OR Strata } \\
(95 \% \mathrm{Cl})\end{array}$} & \multirow{2}{*}{$\begin{array}{c}\text { Crude } \\
\text { OR }\end{array}$} & \multirow[t]{2}{*}{ M-H OR } & \multirow{2}{*}{$\begin{array}{l}\text { Selisih } \\
\text { OR }\end{array}$} \\
\hline & & $\mathbf{n}$ & $\%$ & $n$ & $\%$ & & & & \\
\hline \multirow[t]{2}{*}{ Anemia } & BBLR & 30 & 44,78 & 37 & 55,22 & $\begin{array}{c}2,43 \\
(0,39-26,06)\end{array}$ & 3,03 & 2,88 & $4,95 \%$ \\
\hline & Normal & 2 & 25,00 & 6 & 75,00 & 1 & & & \\
\hline \multirow[t]{2}{*}{$\begin{array}{l}\text { Tidak } \\
\text { anemia }\end{array}$} & BBLR & 91 & 54,82 & 75 & 45,18 & $\begin{array}{c}3,24 \\
(0,74-19,47)\end{array}$ & & & \\
\hline & Normal & 3 & 27,27 & 8 & 72,73 & 1 & & & \\
\hline
\end{tabular}

stunting 2,43 kali lebih tinggi. Selisih OR antara Crude OR dengan Maentel Haenzel OR adalah $4,95 \%$, selisih OR ini kurang dari $20 \%$ yang berarti bahwa riwayat anemia bukan merupakan variabel confounding hubungan antara riwayat BBLR dengan kejadian stunting. Bila dilihat nilai OR di setiap strata, ternyata OR strata riwayat anemia tidak berbeda dengan OR strata riwayat tidak anemia atau OR $1=$ OR 2, berarti bahwa riwayat anemia bukan merupakan efek modifikasi hubungan antara riwayat BBLR dengan kejadian stunting.

\section{BAHASAN}

\section{Hubungan riwayat anemia saat hamil dengan kejadian stunting pada anak usia 6-23 bulan}

Penambahan kebutuhan energi untuk ibu hamil pada trimester I adalah $180 \mathrm{kkal}$ dan pada trimester II dan III masing-masing sebesar 300 kkal. Penambahan kebutuhan protein untuk ibu hamil pada tiap trimester adalah 17 gram (11). Seorang ibu hamil yang tidak tercukupi zat gizinya akan mengalami anemia, yang akan meningkatkan risiko kelahiran BBLR (12). BBLR sendiri akan meningkatkan risiko terjadinya stunting pada balita (13). Pada penelitian ini, riwayat anemia saat hamil merupakan faktor risiko terjadinya stunting yang secara statistik tidak signifikan $(p=0,08, O R=1,65)$. Berdasarkan Tabel 3, lebih dari separuh anak stunting di Kecamatan Sedayu ibunya menderita anemia saat hamil $(57,33 \%)$. Setelah dilakukan analisis stratifikasi, berdasarkan Tabel 8, sekitar 44,78 $\%$ ibu yang menderita anemia saat hamil di Kecamatan Sedayu melahirkan bayi dengan berat badan yang rendah. Dengan demikian ibu yang anemia saat hamil berpengaruh terhadap berat badan bayi. Faktor lain yang berpengaruh terhadap pertumbuhan dan perkembangan bayi termasuk panjang badan bayi setelah bayi lahir adalah keturunan, kondisi lingkungan, penyakit infeksi, dan usia pengenalan MP-ASI terlalu dini $(11,14,15)$. Hasil penelitian ini sejalan dengan penelitian yang menyatakan bahwa riwayat penyakit kehamilan termasuk anemia merupakan faktor risiko kejadian stunting $(16,17)$.

\section{Hubungan riwayat KEK saat hamil dengan kejadian stunting pada anak usia 6-23 bulan}

Riwayat KEK saat hamil secara statistik tidak berhubungan dengan kejadian stunting pada balita $(\mathrm{OR}=0,61,95 \% \mathrm{Cl}=0,32-1,14)$. Penelitian ini didukung penelitian di Butajira, Ethiopia (14). Penelitian berbeda yang dilakukan di Yogyakarta, menyatakan ada hubungan antara kekurangan energi kronis saat hamil dengan kejadian stunting pada balita usia 6-24 bulan (18). Tidak adanya hubungan ini karena kesadaran ibu hamil di Kecamatan Sedayu untuk memeriksakan kehamilannya minimal 4 kali sudah tinggi yaitu $50,21 \%$ pada kelompok kasus seperti pada Tabel 3. Dengan demikian ibu hamil yang sejak awal sudah diketahui mengalami kekurangan energi kronis dapat segera ditangani oleh petugas kesehatan, sehingga dapat dilakukan intervensi sedini mungkin. Intervensi yang diberikan kepada ibu hamil dapat meningkatkan status gizinya termasuk meningkatkan berat badan bayi dan panjang badan bayi. Adanya program pemberian makanan tambahan (PMT) bagi ibu hamil yang menderita kurang energi kronis di Kecamatan Sedayu merupakan salah satu bentuk intervensi yang diberikan sehingga bayi di dalam kandungan dapat tetap tumbuh dan berkembang dengan baik.

Kemungkinan yang menyebabkan stunting, adalah adanya faktor lain yang dialami bayi setelah 
lahir yaitu pada saat bayi mulai mendapatkan MPASI adalah ketahanan pangan rumah tangga yang kurang. Hasil analisis bivariat menunjukkan bahwa rawan pangan berhubungan secara signifikan dengan kejadian stunting $(p=0,04, O R=2,70,95 \%$ $\mathrm{Cl}=1,04-7,00)$. Rumah tangga yang rawan pangan berarti ada masalah tentang pangan di dalam keluarga tersebut, baik jumlah maupun jenisnya. Hal ini akan berpengaruh juga terhadap asupan zat gizi pada bayi. Bayi yang sudah mulai mendapatkan makanan pendamping ASI, karena jumlah dan jenis bahan makanan yang terbatas di dalam keluarga, akan terbatas pula asupan zat gizinya sehingga menderita stunting (19).

Dari analisis stratifikasi riwayat BBLR pada hubungan riwayat KEK dengan kejadian stunting, diperoleh nilai OR pada strata riwayat BBLR adalah 0,67 dan pada strata riwayat berat bayi lahir normal adalah 0,72 yang berarti bahwa jika ibu menderita KEK saat hamil dan anak waktu lahir mempunyai riwayat BBLR maupun tidak BBLR maka akan menjadi faktor proteksi terhadap kejadian stunting. Riwayat KEK yang bersifat protektif ini dapat disebabkan pada saat hamil, ibu yang menderita KEK mendapatkan intervensi berupa PMT. Dengan pemberian makanan tambahan pada ibu hamil yang KEK akan meningkatkan status gizi ibu dan bayi yang dikandungnya.

Selain itu, data riwayat KEK yang diambil merupakan data sekunder, sehingga ada kemungkinan data tidak akurat. Demikian juga penambahan berat badan ibu selama hamil tidak diambil datanya sehingga tidak diketahui penambahan berat badan ibu selama hamil cukup atau kurang. Hasil analisis stratifikasi riwayat BBLR pada hubungan riwayat kurang energi kronis saat hamil dengan kejadian stunting diperoleh bahwa riwayat BBLR bukan merupakan variabel confounding dan bukan efek modifikasi pada hubungan riwayat KEK saat hamil dengan kejadian stunting.

\section{Hubungan variabel luar dengan kejadian stunting pada anak usia 6-23 bulan}

Persentase anak stunting yang mempunyai riwayat $B B L R$ lebih tinggi daripada balita stunting yang lahir dengan berat badan normal yaitu $73,68 \%$. Berdasar analisis bivariat, diperoleh nilai $p=0,03$, yang berarti bahwa ada hubungan yang signifikan antara riwayat BBLR dengan kejadian stunting. Kekuatan hubungan diperoleh nilai OR=3,03 (95\% $\mathrm{Cl}: 1,09-8,33)$ yang berarti balita yang lahir dengan riwayat BBLR mempunyai risiko 3,03 kali lebih tinggi akan menderita stunting. Setelah dianalisis multivariat, riwayat BBLR tidak berhubungan secara signifikan dengan kejadian stunting. Hasil penelitian ini didukung oleh penelitian yang dilakukan di Semarang Timur yang menyatakan bahwa berat badan lahir bukan merupakan faktor risiko terjadinya stunting (16). Penelitian yang berbeda menyatakan bahwa balita yang lahir dengan riwayat BBLR mempunyai risiko 5,6 kali lebih tinggi untuk menderita stunting (20). Begitu pula penelitian pada 6.956 anak usia 6-23 bulan di Indonesia tahun 2013 (21). Tidak adanya hubungan antara riwayat BBLR dengan kejadian stunting di Kecamatan Sedayu kemungkinan karena sebagian besar bayi lahir dengan berat badan normal yaitu 112 anak pada kasus dan 121 anak pada kontrol. Selain itu, efek terbesar berat badan lahir terhadap stunting adalah pada usia 6 bulan awal, kemudian menurun hingga usia 2 tahun. Jika bayi yang lahir dengan riwayat BBLR dapat tumbuh kejar (catch up grow) pada 6 bulan pertama, maka bayi tersebut dapat tumbuh dengan tinggi badan normal (22).

Tinggi badan ibu merupakan satu-satunya variabel luar yang berhubungan secara signifikan dengan stunting $(p=0,01, O R=2,17,95 \% \mathrm{Cl}: 1,24$ $3,79)$. Penelitian ini sejalan dengan penelitian yang dilakukan di Semarang Timur, yang menyatakan bahwa tinggi badan ibu yang rendah memiliki risiko 10,3 lebih tinggi anaknya menderita stunting. Akan tetapi, penelitian ini berbeda dengan penelitian yang dilakukan di Kota Semarang yang menyebutkan bahwa tinggi badan ibu tidak berhubungan dengan stunting $(16,23)$. Bila kondisi pendek pada ibu karena memiliki gen dalam kromosom yang membawa sifat pendek, kemungkinan anak mempunyai peluang lebih besar membawa sifat pendek dan tumbuh menjadi stunting, tetapi bila tinggi badan yang pendek pada ibu ini disebabkan kurangnya gizi atau penyakit maka kemungkinan anak akan dapat tumbuh dengan normal selama anak tidak terpapar oleh faktor risiko lain (24). Anak yang stunting 
di Kecamatan Sedayu kemungkinan pada awal pertumbuhannya dipengaruhi oleh genetik. Kondisi biologis ibu saat hamil dan menyusui tetapi setelah memasuki usia pengenalan MP-ASI, kualitas dan kuantitas makanan sangat mempengaruhi pertumbuhan anak, karena ketahanan pangan di dalam keluarga yang rendah (25).

Hasil bivariat dari penelitian ini menunjukkan ada hubungan yang signifikan antara ketahanan pangan dengan kejadian stunting karena diperoleh nilai $p=0,04(\mathrm{OR}=2,7,95 \% \mathrm{Cl}: 1,04-7,00)$. Analisis multivariat tidak ada hubungan antara ketahanan pangan dengan kejadian stunting, karena variabel yang dianalisis tidak hanya ketahanan pangan saja tetapi juga variabel lain yaitu riwayat anemia ibu saat hamil, riwayat BBLR serta tinggi badan ibu, sehingga faktor-faktor tersebut diduga berpengaruh terhadap stunting. Penelitian lain menyatakan bahwa tidak ada hubungan antara ketahanan pangan dengan kejadian stunting di Kecamatan Biboki Utara, Kabupaten Timor Tengah Utara. Penelitian di Kailali, Nepal menyatakan bahwa pada analisis multivariat tidak ada hubungan antara ketahanan pangan dengan kejadian stunting. Kejadian stunting sendiri lebih dipengaruhi oleh faktor lain yaitu pengetahuan ibu, pola asuh, status gizi ibu, akses ke tempat pelayanan kesehatan, kesehatan lingkungan serta pembagian dan pemanfaatan makanan bagi anggota keluarga. Hasil penelitian lain yang berbeda menyebutkan bahwa ketahanan pangan berhubungan dengan status gizi balita (26-28).

Berdasarkan Tabel 5, persentase anak stunting yang pekerjaan orang tuanya tidak tetap, lebih tinggi daripada yang tidak stunting, yaitu $51,21 \%$ pekerjaan ibu tidak tetap dan $53,42 \%$ pekerjaan ayah tidak tetap. Pekerjaan yang tidak tetap ini menyebabkan pendapatan yang diperoleh setiap bulannya juga tidak tetap, sehingga menyebabkan terbatasnya daya beli keluarga terhadap bahan makanan yang berkualitas dan mencukupi jumlahnya. Keterbatasan bahan makanan dalam keluarga menyebabkan asupan zat gizi pada anak-anak tidak optimal. Bila keterbatasan ini berlangsung dalam jangka waktu yang lama akan menyebabkan gangguan pertumbuhan dan perkembangan anak yaitu menjadi stunting.

Adanya program-program pemerintah yang memberikan bantuan kepada masyarakat kurang mampu seperti bantuan langsung tunai dan program beras miskin (raskin) menyebabkan ketersediaan pangan di dalam rumah tangga rawan pangan membaik, sehingga asupan energi dan protein khususnya pada anak usia 6-23 bulan juga membaik. Hal ini didukung data asupan energi dan protein pada Tabel 4 bahwa asupan energi dan protein memiliki hubungan yang tidak signifikan dengan kejadian stunting. Hal ini berarti bahwa antara keluarga yang rawan pangan dan keluarga yang tahan pangan tidak ada perbedaan dalam hal pemenuhan kebutuhan energi dan protein pada anak usia 6-23 bulan.

\section{KESIMPULAN DAN SARAN}

Tidak ada hubungan antara riwayat KEK dan anemia ibu saat hamil dengan kejadian stunting di Kecamatan Sedayu Bantul, Yogyakarta. Anak yang menderita stunting sebagian besar berasal dari keluarga yang tinggi badan ibunya kurang, keluarganya mengalami rawan pangan dan lahir dengan riwayat BBLR. Setelah dilakukan analisis multivariat, didapatkan hasil bahwa ada hubungan antara kejadian stunting dengan tinggi badan ibu yang kurang. Saran dalam penelitian ini agar anak tidak lahir dengan berat bayi lahir rendah dan tidak menderita stunting perlu penanganan sejak awal kehamilan. Untuk menurunkan angka prevalensi KEK dan anemia, maka ibu hamil dianjurkan mengkonsumsi makanan yang beranekaragam serta porsinya lebih banyak dari sebelum hamil, melakukan pemeriksaan kehamilan secara teratur, bila menderita anemia dianjurkan mengonsumsi tablet tambah darah. Perlu penyuluhan dan pemeriksaan pada remaja putri dan wanita usia subur, sehingga bila ditemukan remaja putri dan wanita usia subur yang menderita kurang energi kronis maupun anemia dapat dilakukan intervensi sedini mungkin sehingga pada waktu hamil tidak menderita kurang energi kronis dan anemia. 


\section{RUJUKAN}

1. Narendra M, Sularyo T, Soetjiningsih, Suyitno S, Ranuh I, Wiradisuria S. Tumbuh kembang anak dan remaja. Jakarta: Sagung Seto; 2002.

2. Badan Penelitian dan Pengembangan Kesehatan. Riset kesehatan dasar tahun 2010. Kementerian Kesehatan RI; 2010.

3. Kementerian Kesehatan Republik Indonesia. Keputusan Menteri Kesehatan Republik Indonesia Nomor: 1995/Menkes/SK/XII/2010. 2011.

4. UNICEF. Nutrition in the First 1,000 Days. The State of the World's Children. Westport: Johnson\&Johnson, Matel,Inc. and Brookstone; 2012.

5. Shrimpton R, Kachondham Y. Analysing the causes of child stunting in DPRK. New York: UNICEF; 2003.

6. Psacharopoulos G, Patrinos H. Returns to investment in education: a further update. Educ Econ. 2004;12:111-34.

7. Badan Penelitian dan Pengembangan Kesehatan. Riset kesehatan dasar tahun 2013. Jakarta: Kementerian Kesehatan RI; 2013.

8. Dinas Kesehatan Kabupaten Bantul. Profil gizi dinas kesehatan Kabupaten Bantul. Bantul: Dinas Kesehatan Kabupaten Bantul; 2012.

9. Lemeshow S, Hosmer JD, Klar J, Lwanga S. Besar sampel dalam penelitian kesehatan. Yogyakarta: Gadjah Mada University Press; 1997.

10. Prasetyo B, Jannah L. Metode penelitian kuantitatif. Jakarta: PT. Raja Grafindo Persada; 2010.

11. Almatsier S, Soetardjo S, Soekatri M. Gizi dalam daur kehidupan. Jakarta: PT. Gramedia Pustaka Utama; 2011.

12. Mumbare S, Maindarkar G, Darade R, Yenge $\mathrm{S}$, Tolani M, Patole K. Maternal risk factors associated with term low birth weight neonates: a matched-pair case control study. Indian J Pediatr. 2012;25:49.

13. Rahmaniah, Huriyati E, Irwanti W. Riwayat asupan energi dan protein yang kurang bukan faktor risiko stunting pada anak usia 6-23 bulan. J Gizi Diet Indones. 2014; 2(3): 150-58.
14. Medhin G, Hanlon C, Dewey M, Alem A, Tesfaye F, Worku B, et al. Prevalence and predictors of undernutrition infants aged six and twelve months in Butajira, Ethiopia: The P-MaMiE birth cohortitle. BMC Public Health. 2010;10:27.

15. Amin N, Julia M. Faktor sosio demografi dan tinggi badan orang tua serta hubungannya dengan kejadian stunting pada balita usia 6-23 bulan. J Gizi dan Diet Indones. 2014; 2(3): 170-77.

16. Nasikhah R, Margawati A. Faktor risiko kejadian stunting pada balita usia 24-36 bulan di Kecamatan Semarang Timur. JNC. 2012;1:715-30.

17. Ruaida N. Hubungan anemia ibu hamil dengan kejadian stunting pada anak usia 6-24 bulan di Kota Yogyakarta. Universitas Gadjah Mada; 2013.

18. Sartono. Hubungan kurang energi kronis ibu hamil dengan kejadian stunting pada anak usia 6-24 bulan di Kota Yogyakarta. Universitas Gadjah Mada; 2014.

19. Soekirman. Ilmu gizi dan aplikasinya untuk keluarga dan masyarakat. Jakarta: Dirjen Dikti; 2000.

20. Nasution D. Hubungan berat badan lahir rendah (BBLR) dengan kejadian stunting pada anak usia 6-24 bulan di Kota Yogyakarta. Universitas Gadjah Mada; 2014.

21. Paramashanti B, Hadi H, Gunawan I. Pemberian ASI eksklusif tidak berhubungan dengan stunting pada anak usia 6-23 bulan di Indonesia. J Gizi dan Diet Indones. 2015: 3(3): 162-74.

22. Age-specific determinants of stunting in Filipino children. Adair,LS Guilkey, DK. J Nutr. 1997;127:314-20.

23. Candra C, Puruhita N, Susanto J. Risk factors of stunting among 1-2 Years old children in Semarang City. MMI. 2011;45(3).

24. Amigo $\mathrm{H}$, Buston $\mathrm{P}$, Radrigan $\mathrm{M}$. Is there a relationship between parent's short height and their children's? Sosial interclass epidemiologic study. Rev Med Chil. 1997;125:8.

25. Addo O, Stein A, Fall C, Gigante D, Guntupalli A, Horta B, et al. Maternal height and child growth patterns from birth to Adulthood. J Pediatr. 2013;163(2):549-54. 
26. Nabuasa C. Hubungan riwayat pola asuh, pola makan, asupan zat gizi terhadap kejadian stunting pada anak usia 24-59 bulan di Kecamatan Biboki Utara Kabupaten Timor Tengah Utara Propinsi Nusa Tenggara Timur. Universitas Gadjah Mada; 2011.

27. Osei A, Rana P, Spiro D, Haselow N, Quinn V, Nielsen J. Household food insecurity and nutritional status of children aged 6 to 23 months in Kailali District of Nepal. Food Nutr Bull. Nevin Scrimshaw International Nutrition Foundation; 2010;31:483-94.

28. Slamet R. Hubungan antara tingkat ketahanan pangan rumah tangga dengan status gizi balita pada rumah tangga di daerah rawan pangan Kabupaten Indramayu. Universitas Gadjah Mada; 2011. 